BISMA

(Bisnis dan Manajemen)
Volume 12, Issue 1, October 2019, 15-28

ISSN 2549-7790 (Online)

ISSN 1979-7192 (Print)

DOI: 10.26740/bisma.v12n1.p15-28

https://journal.unesa.ac.id/index.php/bisma/index

\title{
Difference between financial intelligence on millennials, Gen X, and baby boomers
}

\author{
Njo Anastasia $^{1 *}$, Oka Christian Setiadiwiria ${ }^{2}$, and Yohanes Sondang Kunto ${ }^{3}$ \\ ${ }^{1}$ Finance Program, Faculty of Business and Economics, Universitas Kristen Petra \\ Jalan Siwalankerto No.121-131, Surabaya 60236, Indonesia \\ anas@petra.ac.id
}

${ }^{2}$ Finance Program, Faculty of Business and Economics, Universitas Kristen Petra Jalan Siwalankerto No.121-131, Surabaya 60236, Indonesia

setiadiwiria@gmail.com

${ }^{3}$ Wageningen University \& Research, School of Social Sciences

PB Wageningen, 6708, Netherlands

yohanes.kunto@wur.nl

\begin{abstract}
The financial management of each individual depends on his financial intelligent. This study aims to examine the differences between financial knowledge and financial behavior, which are a combination of financial intelligent in each generation, namely the millennials, Gen X, and baby boomers. The sample used consisted of 100 respondents in each generation, selected using purposive sampling technique. Data collection used questionnaires distributed by online and hardcopy, which is then processed to test the differences using the ANOVA test. The results of the analysis showed that there are significant differences in financial intelligence on millennials, Gen X, and baby boomers. However, there were no difference in financial intelligence between millennials and Gen $X$. This proves that differences in generations that have different growth periods will have different levels of financial knowledge, resulting in differences in financial behavior.
\end{abstract}

Keywords: baby boomers; financial behavior; financial intelligence; financial knowledge; Gen X; millennials.

Received: June 24, 2019; Accepted: August 21, 2019; Published: October 17, 2019

*Corresponding author

Email: anas@petra.ac.id

\section{How to cite this document:}

Anastasia, N., Setiadiwiria, O.C., \& Kunto, Y.S. (2019). Difference between financial intelligence on millennials, Gen $\mathrm{X}$, and baby boomers. BISMA (Bisnis dan Manajemen), 12(October), 15-28. https://doi.org/10.26740/bisma.v12n2.p15-28 


\begin{abstract}
Abstrak
Pengelolaan keuangan tiap individu bergantung pada financial intelligent-nya yang dimiliki individu tersebut. Penelitian ini bertujuan menguji perbedaan financial knowledge dan financial behavior yang merupakan kombinasi financial intelligent pada masingmasing generasi, yaitu gen millennial, Gen X, dan baby boomers. Sampel yang digunakan berjumlah 100 responden pada masing-masing generasi yang dipilih dengan teknik purposive sampling. Pengumpulan data menggunakan kuesioner yang disebarkan secara online dan hardcopy, kemudian data diolah untuk menguji perbedaan tersebut menggunakan uji Anova. A bahwa terdapat perbedaan financial intelligence yang signifikan pada gen millennial, Gen X, dan gen baby boomers. Namun financial intelligence tidak menunjukkan perbedaan antara gen millennial dan Gen X. Hal ini membuktikan bahwa perbedaan beda generasi yang periode pertumbuhannya cukup jauh berbeda akan memiliki tingkat pengetahuan keuangan yang berbeda, sehingga terjadi perbedaan perilaku keuangan.
\end{abstract}

Kata kunci: baby boomers; financial behavior; financial intelligence; financial knowledge; Gen X; millennials.

\title{
INTRODUCTION
}

Financial intelligence is one of the aspects to measure intelligence regarding financial knowledge. Financial intelligence is an individual's ability to solve financial problems and his attitude to improve financial knowledge in order to demonstrate a good financial behavior (Kiyosaki, 2008). Individuals who lack financial knowledge can have a detrimental impact on themselves both in the short and long term. Whereas financial knowledge is the knowledge one possesses in finance (Bashir, Arshad, Nazir, \& Afzal, 2013). Said financial knowledge includes the knowledge of personal finance management, savings, and investing that each individual has, thus affecting the mindset and his view towards financial management. Furthermore, financial behavior relates to how individuals treat, manage, and use their money. Individuals with a good financial behavior tend to use their money effectively, such as planning budgets, saving money, controlling their spending, investing, and paying their obligations on time (Nababan \& Sadalia, 2012).

The existence of three generations, namely millennials, Gen X, and baby boomers with diversity in each generation such as mindset and different characteristics of finance, needs further study. These differences are reflected in previous studies. Dent (2017) states that 59\% of millennials use technology for their financial activities, while Gen X only $40 \%$ and baby boomers $24 \%$. 52\% of millennials associate the words "risk" and "investment" with opportunity, while $55 \%$ of Gen X associates them with "inconvenience" and $58 \%$ of baby boomers associate them with "uncertainty". The financial behavior of the millennials is to invest (35\%), Gen X (26\%) and baby boomers (25\%); where millennials (41\%) get investment advice from friends, family or colleagues, while Gen X (31\%) and baby boomers $(19 \%)$ hesitate to talk about money. The investment products selected by 
$60 \%$ of Gen $\mathrm{X}$ are investment products such as bonds, cash, and stocks that have been profitable in the past, while $76 \%$ of baby boomers prefer gold and property. According to Hawkins \& Mothersbaugh (2013), millennials have better opportunities and quality of life than previous generations, thus possessing high self-esteem, daring to risk and having their own financial perspective. Education level of the millennials are higher compared to previous generations, but millennial is inconsistent in their financial life (Idris, Krishnan, \& Azmi, 2013). Research regarding financial intelligence on three generations is still limited, so it needs further revelation. The aim of this study is to test the differences of financial intelligence in each generation as measured by financial knowledge and financial behavior on millennial, Gen X, and baby boomers. The differences among these three generations that will be disclosed is expected to give an insight to the financial intelligence on each generation, so action and decision-making that will be carried out will give better results.

\section{Financial Intelligence}

Having money without financial intelligence to accompany it might result in a loss of money. When an individual has a high level of financial intelligence, he will be able to figure out what to do with the money, how to prevent others from taking it, how to keep it longer, and how to make the money work for the individual. So, individuals with financial intelligence are characterized by having the high financial knowledge and good financial behavior (Kiyosaki, 2008). Financial intelligence fundamentally consists of understanding the foundation, individuals with a basic understanding of financial knowledge in general, such as asset liquidity, net worth calculations, and personal financial planning; and understanding the art, individuals who can identify financial aspects to be applied and how to apply financial knowledge in everyday life (Berman, Knight, \& Case, 2013).

Chen \& Volpe (1998) say that financial knowledge is an individual's knowledge of financial management that includes current and future needs. Grable, Park, \& Joo (2009) cite many sources to gain financial knowledge, such as formal education such as school or college, seminar, training outside formal education, and informal sources such as parents, friends, work environment or even unpleasant personal experience. Hilgert \& Hogarth (2003) also say that knowledge of financial management and investing technique will be needed and will not be as negligible as it is in the past. Financial knowledge becomes an essential knowledge of the various basic concepts of finance such as knowledge of risk diversification, nominal and real value differences, knowledge of time value of money, and many others so that the goal of welfare can be achieved (Lusardi, 2008). Aspects of financial knowledge are divided into: (1) Financial knowledge in general or overall. One's knowledge regarding asset liquidity, net worth calculations, and personal finance planning; (2) Knowledge of savings and loans. One's knowledge regarding credit 
cards, credit cards report compound interest, deposit insurance, credit card usage, loan interest rates, and savings and deposit interest rate; and (3) Knowledge of investment. One's knowledge regarding investment products such as bonds, gold, and more. The profits earned can be used for other investments, such as foreign currencies, bonds, and other bearable risks (Chen \& Volpe, 1998).

The financial knowledge one possesses will guide the individual's behavior in making decisions. Financial behavior is the attitude and behavior of an individual in financial management (Hira \& Mugenda, 1999) with a measure in spending and saving behavior. The study of Xiao, Chen, \& Chen (2013) also uses the same indicators for daily financial activities, such as planning for emergency funds, pension funds, comparing credit offers and control of financial posts which use credit and debit cards, as well as tracking monthly spending as a financial behavior indicator.

Generation is a group of individuals consisting of individuals of the same age range who have experienced the same historical events in the same period (Ryder, 1965). Borodin, Smith, \& Bush (2010) state that people of the same generation have similarities in culture, politics, economics, world events, natural disasters and technology, thus forming the same views, values, options, and beliefs. As a result, each generation experiences different experience and perspective on values, expectations, and work attitude, resulting in a different outcome (Smith, Roebuck, \& Elhaddaoui, 2013).

Millennial have financial knowledge through mastering technology in their financial life, but Gen X is higher compared to baby boomers, as millennial are born in an era where information and knowledge is easily obtainable, while baby boomers are born in a developing era. As such, millennial have a better opportunity than baby boomers. This condition results in risk profile of millennial to be risk takers, Gen X to be moderate, and baby boomers to be more conservative. 52\% of millennial states investing is an "opportunity", $55 \%$ of Gen X states investing is an "inconvenience", while to $58 \%$ of baby boomers it is an "uncertainty". This profile makes millennial tend to allocate their funds in lifestyle (gadgets, traveling, and hangouts), while Gen X tend to use their funds for venture capital and school costs of children, and baby boomers prefer investing in the form of houses and land (Dent, 2017).

Individual's financial knowledge will drive them to act and make decisions, such as saving behavior, which is more common in millennial (35\%), compared to baby boomers (25\%) and Gen X (26\%). Knowledge is obtained by listening feedback from other people regarding investments. As a result, millennial decisions are more focused on mutual funds and stocks, Gen X prefers bonds and deposits, and baby boomers prefer properties.

Based on the description above, the hypotheses in this study are: 
H1: There are financial knowledge differences between millennials, baby boomers, and Gen X.

$\mathrm{H} 2$ : There are differences in financial behavior between millennials, baby boomers, and Gen X

\section{METHODS}

This study is a comparative study, which compares one or more variables on two or more different samples or at different times (Sugiyono, 2017). The population in this study is all the residents of Surabaya and selected with sample criteria according to the purposive sampling technique. 100 respondents are taken from each sample according to sample criteria, which is (1) baby boomers, born in 1946-1964, or 53-71 years old, (2) Gen X, born in 1965-1981, or 36-52 years old, and (3) millennials, born in 1982-1991, or 26-35 years old (Oblinger \& Oblinger, 2005). The research variables can be seen in table 1 .

Table 1. Research Variable

\begin{tabular}{|c|c|c|}
\hline Variable & Indicator & Analysis \\
\hline $\begin{array}{c}\text { Financial } \\
\text { Knowledge }\end{array}$ & $\begin{array}{l}\text { Statements measuring an individual's } \\
\text { financial knowledge or general } \\
\text { knowledge, saving, and investing } \\
\text { (Chen \& Volpe, 1998) }\end{array}$ & $\begin{array}{l}\text { Every correct answer is given } \\
1 \text { point, then the sum is } \\
\text { divided with the total number } \\
\text { of questions }\end{array}$ \\
\hline $\begin{array}{l}\text { Financial } \\
\text { Behavior }\end{array}$ & $\begin{array}{l}\text { Statements measuring an individual's } \\
\text { spending and saving behavior } \\
\text { (Grable, Park, \& Joo, 2009) }\end{array}$ & $\begin{array}{l}\text { In every question, respondents } \\
\text { select a Likert scale with the } \\
\text { following conditions: } \\
\text { Strongly disagree; Disagree; } \\
\text { Fairly agree; Agree; Strongly } \\
\text { agree }\end{array}$ \\
\hline
\end{tabular}

Source: Result of the research.

Data collection used questionnaires distributed online and offline according to age-specific sample criteria. Offline questionnaires were distributed in shopping malls and several campuses in Surabaya within three weeks. The data analysis technique used was ANOVA test to test the differences between generations related to financial intelligence.

\section{RESULT AND DISCUSSION}

\section{Result}

Questionnaires were distributed both online and offline to 100 respondents of each age group specified in sample criteria (according to each generation). Respondent's demographic background in all three categories can be seen in Appendix 1. Female respondents dominated the proportion of Gen $X$ and millennials. While in baby boomers, male respondents were dominant.

Most baby boomers and Gen X are married and have 3 children, while many millennials are still unmarried (29\%). The highest education of baby boomers was mainly junior high and high school (52.7\%), while Gen X and millennials had a bachelor's degree $(31.7 \%)$. Employment as a private employee $(65 \%)$ is the most 
popular in all three generations and most have an income range of Rp.3.000.000 Rp.5.000.000 (41.7\%) Gen X and millennials (14\%) had higher incomes in the Rp.7.500.000 - Rp.10.000.000 range. In the millennials, there are respondents with income below Rp.1.000.000, - since they were still in college with part-time job income, as well as generation $\mathrm{X}$ entering retirement age.

Respondent's description of study results showed that 70 respondents (23.34\%) have financial knowledge between 0-50, while 230 respondents $(76.66 \%)$ scored 50.1-100. The average value of millennials' financial knowledge (78.98) is higher compared to Gen X (77.37) and baby boomers (58.78).

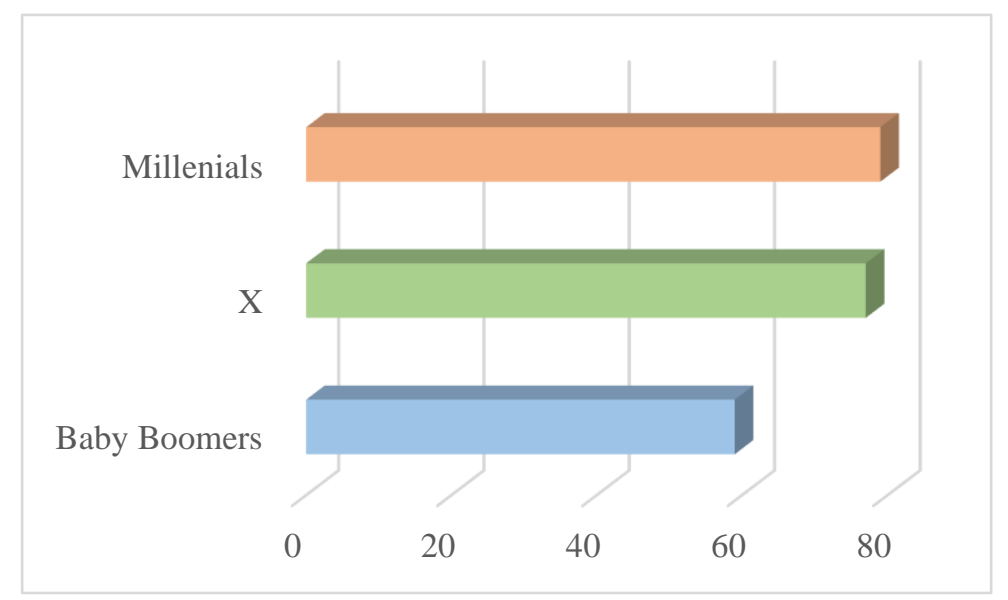

Figure 1. Mean Value of Financial Knowledge in Each Generation

Figure 2 shows 64 respondents $(27.33 \%)$ have low financial behavior, and 218 respondents $(72.67 \%)$ have high financial behavior. The average value of millennials (4.17) is higher compared to Gen X (4.06) and baby boomers (2.42).

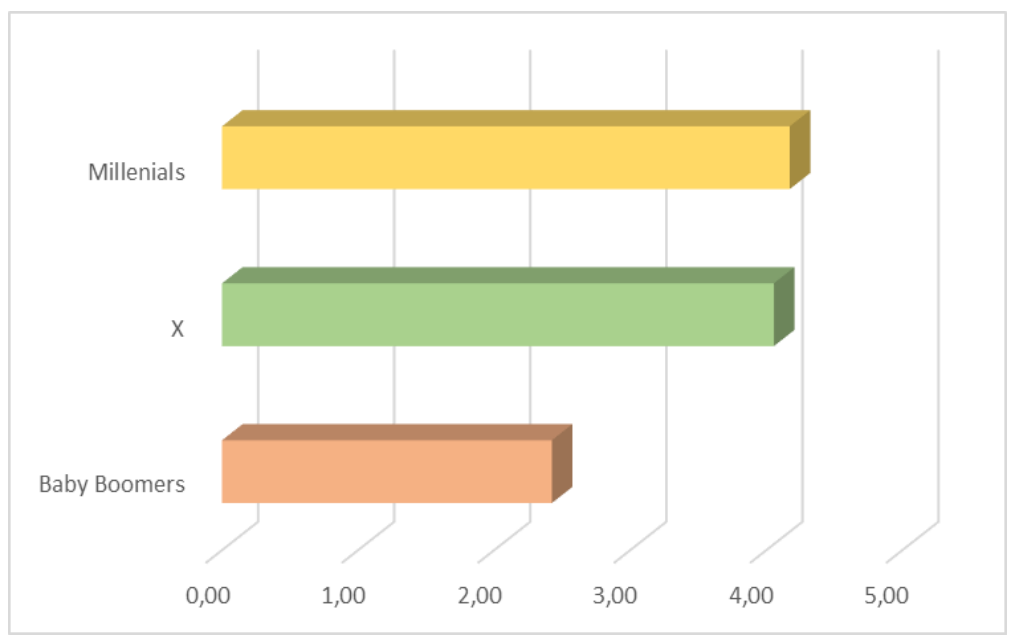

Figure 2. Mean Value of Financial Behavior in Each Generation

Before testing the differences between variable, validity and reliability test was done on the indicators used to measure financial behavior variables. Validity 
test results showed that all indicators were significant $(\mathrm{p}$-value $<0.05)$ and Cronbach Alpha value above 0.6 on Table 2, thus meeting the criteria for further use in the ANOVA test.

Table 2. Validity and Reliability Test Result in Three Generations

\begin{tabular}{|c|c|c|c|c|}
\hline \multirow[b]{2}{*}{ No } & \multirow[b]{2}{*}{ Indicator } & \multicolumn{3}{|c|}{ Validity Test - Pearson Correlation } \\
\hline & & $\begin{array}{c}\text { Gen } \\
\text { Baby Boomers }\end{array}$ & $\begin{array}{c}\text { Gen } \\
\text { X }\end{array}$ & $\begin{array}{c}\text { Gen } \\
\text { Millennials } \\
\end{array}$ \\
\hline 1 & FB1 & $0.801 * *$ & $0.747 * *$ & $0.821 * *$ \\
\hline 2 & FB2 & $0.672 * *$ & $0.678 * *$ & $0.724 * *$ \\
\hline 3 & FB3 & $0.755 * *$ & $0.772 * *$ & $0.847 * *$ \\
\hline 4 & FB4 & $0.736 * *$ & $0.707 * *$ & $0.834 * *$ \\
\hline 5 & FB5 & $0.867 * *$ & $0.725 * *$ & $0.681 * *$ \\
\hline 6 & FB6 & $0.801 * *$ & $0.747 * *$ & $0.821 * *$ \\
\hline 7 & FB7 & $0.672 * *$ & $0.678 * *$ & $0.724 * *$ \\
\hline 8 & FB8 & $0.755^{* *}$ & $0.772 * *$ & $0.847 * *$ \\
\hline 9 & FB9 & $0.736 * *$ & $0.707 * *$ & $0.834 * *$ \\
\hline 10 & FB10 & $0.867 * *$ & $0.725 * *$ & $0.681 * *$ \\
\hline \multicolumn{2}{|c|}{ Cronbach Alpha } & 0.921 & 0.897 & 0.928 \\
\hline
\end{tabular}

Description: ** p-value $<0.05$; Cronbach Alpha $>0.6$

Source: Result of the research.

The results of the financial intelligence test on all three generations measured from financial knowledge and financial behavior are shown in Table 3.

Table 3. Differences in Financial Intelligent in Three Generations

\begin{tabular}{cccc}
\hline Variable & Mean & $\begin{array}{c}\text { Mean } \\
\text { Difference } \\
(\mathbf{I}-J)\end{array}$ & Std. Error \\
\hline Financial Knowledge & & & \\
Gen Baby Boomers vs & 58.775 & -18.5925 & $2.743 * * *$ \\
Gen X & 77.367 & & \\
Gen Baby Boomers vs & 58.775 & -20.2020 & $2.696 * * *$ \\
Gen Millennials & 78.976 & & 2.407 \\
Gen Millennials vs & 78.976 & 1.6095 & \\
Gen X & 77.367 & & $0.861 * * *$ \\
Financial Behavior & & & \\
Gen Baby Boomers vs & 2.424 & -1.6320 & $0.911 * * *$ \\
Gen X & 4.056 & & 0.886 \\
Gen Baby Boomers vs & 2.424 & -1.7480 & \\
Gen Millennials & 4.172 & & \\
Gen Millennials vs & 4.172 & 0.1160 & \\
Gen X & 4.056 & & \\
\hline Note* *** p-value < 0.01 & & &
\end{tabular}

Source: Result of the research.

\section{Discussion}

Baby boomers have differences on financial knowledge and financial behavior compared to Gen X and millennial, but there is no difference between Gen $\mathrm{X}$ and millennial. Financial knowledge difference occurs in baby boomers towards 
millennial and Gen X, as baby boomers were born in an age where the economy was still developing, with a very conservative and cautious nature. The educational background of the majority of respondents is at the junior and senior high levels, so the level of knowledge about finance is limited. As Gen X was born in an era where technology was starting to develop, access to information was easier than the baby boomers. Furthermore, millennial was born in the age of advanced technology and were available in almost every region, so access to information and knowledge was faster and easier than ever before. Millennial are said to be the generation that mastered science and technology. However, the test results showed that there was no financial knowledge difference between Gen $\mathrm{X}$ and millennial, as both generations were born in a relatively similar technological era and most of them were college-educated. The educational background and unlimited access to information perhaps gives both generations' the opportunity to learn independently with the help of the technology.

An individual's knowledge can be used to make decisions. The results of the study in financial behavior showed that the baby boomers were different from the $\mathrm{X}$ and millennial, but there was no behavioral difference between the $\mathrm{X}$ and millennial. The economic condition of the baby boomers is in good condition but has considerable responsibility, so that their low level of knowledge leads to low financial behavior. Their knowledge of investing is influenced by parents who focus on real assets such as deposits, property or gold. On the other hand, millennial is better informed and can consider their options from a broader selection of investment products such as stocks and mutual funds. So is the case in Gen X, though some still prefer deposits as investment products. Product choice decisions relate to the economic conditions or individual income in each generation. Respondents with high financial knowledge tend to have better financial behavior. Adequate financial knowledge can positively affect a person's financial behavior (Robb \& Woodyard, 2011). Lack of knowledge on basic finance can lead to limited retirement planning and create a bad habit in saving money (Lusardi, 2008).

\section{CONCLUSION}

This study shows that there is a difference in financial knowledge and financial behavior between generations, except for the Gen $X$ and millennial. The millennial has the highest financial knowledge and financial behavior, while the baby boomers have the lowest. These differences indicate that different periods of individual growth give different financial-related stimuli to each generation, except for the periods that are near to each other. However, that financial knowledge continues to encourage each generation to make different financial decisions. The choice of investment products selected reflects the level of knowledge possessed by each generation. 
A major limitation of this study is that the number of respondents of each generation needs to be increased to better represent the population. Another limitation is that this study used ANOVA method without control variables. Therefore, it has to rely on a strong assumption that financial intelligent is independent to potential confounders (e.g. education, income, and family structure). This assumption is not necessarily true. Future studies might apply more advance methods such as ANCOVA (Analysis of Covariance) to produce robust results against the assumption and also to understand the factors that influence and differ the financial intelligent of the three generations. Furthermore, this research still needs to be developed by developing parent advice variable or peer influence to deepen the level of financial knowledge, thus enhancing the financial knowledge that each generation has. The involvement of a financial advisor can contribute to the financial knowledge in each generation. As a result, the investment products offered by the people in financial industry will be more variable.

\section{REFERENCES}

Bashir, T., Arshad, A., Nazir, A., \& Afzal, N. (2013). Financial literacy and influence of psychosocial factors. European Scientific Journal, 9(28), 384404.

Berman, K., Knight, J., \& Case, J. (2013). Financial intelligence : a manager's guide to knowing what the numbers really mean. Boston, Mass: Harvard Business Review Press.

Borodin, A., Smith, R., \& Bush, A. (2010). Summary brief: Does generation Y's value toward work, self, and individual responsibility influence their ethicality? Society for Marketing Advances Proceedings, (pp. 112-113).

Chen, H., \& Volpe, R. (1998). An analysis of personal financial literacy among college students. Financial Services Review, 7(2), 107-128.

Dent, A. (2017, December 5). The next generation: Millennials out-invest Gen X and Baby Boomers. Retrieved from The Bonhill Network: https://www.growthbusiness.co.uk/millennials-invest-gen-X-2553142/

Grable, J., Park, J.-Y., \& Joo, S.-H. (2009). Explaining financial management behavior for Koreans living in the United States. Journal of Consumer Affairs, 43(1), 80-107. doi:10.1111/j.1745-6606.2008.01128.x

Hawkins, D., \& Mothersbaugh, D. (2013). Consumer behavior: Building marketing strategy (12th ed.). New York: Mc Graw-Hill Irwin.

Hilgert, M., \& Hogarth, J. (2003, July). Household financial management: The connection between knowledge and behavior. Federal Reserve Bulletin, pp. 309-322. 
Hira, T., \& Mugenda, O. (1999). The relationships between self-worth and financial beliefs, behavior, and satisfaction. Family and Consumer Sciences Research Journal, 91(4), 76-82.

Idris, F. H., Krishnan, S. D., \& Azmi, N. (2013). Relationship between financial literacy and financial distress among youths in Malaysia - an empirical study. Malaysian Journal of Society and Space, 9(4), 106-117.

Kiyosaki, R. T. (2008). Increase your financial IQ: get smarter with your money. New york: Business Plus.

Lusardi, A. (2008, June). Financial literacy: an essential tool for informed consumer choice? NBER Working Paper, 1-29. doi:10.3386/w14084

Nababan, D., \& Sadalia, I. (2012). Analisis personal financial literacy dan financial behavior mahasiswa strata I Fakultas Ekonomi Universitas Sumatera Utara. Retrieved from http://repository.usu.ac.id/handle/123456789/34557.

Oblinger, D. G., \& Oblinger, J. L. (2005). Is It Age or IT: First Steps Toward Understanding the Net Generation. In Educating the Net Generation (pp. 2.12-20). Educause: Transforming Education Through Information Technologies.

Robb, C., \& Woodyard, A. (2011). Financial knowledge and best practise behavior. Journal of Financial Counseling and Planning, 22(1), 60-70.

Ryder, N. (1965). The Cohort as a Concept in the Study of Social Change. American Sociological Review, 30, 843-861. doi:http://dx.doi.org/10.2307/2090964

Smith, D., Roebuck, D., \& Elhaddaoui, T. (2013). Cross-generational perspectives on work-life balance and its impact on women's opportunities for leadership in the workplace. Advancing Women in Leadership, 33, 52-62. Retrieved from http://advancingwomen.com/awl/awl_wordpress/

Sugiyono. (2017). Metode penelitian bisnis: Pendekatan kuantitatif, kualitatif, kombinasi dan R\&D (3rd ed.). Bandung: CV Alfabeta.

Xiao, J. J., Chen, C., \& Chen, F. (2013). Consumer financial capability and financial satisfaction. Social Indicators Research, 113(3), 415-432. doi:10.1007/s11205-013-0414-8

Appendix 1. Descriptive Data

\begin{tabular}{ccccc}
\hline & Millennials & Gen X & Baby Boomers & Total \\
\hline Gender & 39 & 35 & 75 & 149 \\
Male & 61 & 65 & 25 & 151 \\
Female & & & & \\
Status & 83 & 4 & 0 & $87(29.0 \%)$ \\
Not married & 17 & 96 & 100 & $213(71.0 \%)$ \\
Married & & & &
\end{tabular}




\begin{tabular}{|c|c|c|c|c|}
\hline & Millennials & Gen X & Baby Boomers & Total \\
\hline \multicolumn{5}{|l|}{ Education } \\
\hline Junior high school & 6 & 4 & 64 & $74(24.7 \%)$ \\
\hline High school & 34 & 23 & 27 & $84(28.0 \%)$ \\
\hline Diploma & 4 & 22 & 9 & $35(11.7 \%)$ \\
\hline Undergraduate & 54 & 41 & 0 & $95(31.7 \%)$ \\
\hline Graduate & 2 & 10 & 0 & $12(4.0 \%)$ \\
\hline \multicolumn{5}{|l|}{ Occupation } \\
\hline Civil servant & 6 & 25 & 0 & $31(10.3 \%)$ \\
\hline Private employee & 44 & 60 & 91 & $195(65.0 \%)$ \\
\hline Self-employed & 24 & 7 & 9 & $40(13.3 \%)$ \\
\hline Professional & 7 & 8 & 0 & $15(5.0 \%)$ \\
\hline Others & 19 & 0 & 0 & $19(6.3 \%)$ \\
\hline \multicolumn{5}{|l|}{ Income } \\
\hline$<$ Rp. 1.000.000 & 3 & 2 & 0 & $5(1.7 \%)$ \\
\hline \multicolumn{5}{|l|}{$>$ Rp. $1.000 .000-$} \\
\hline 2.000 .000 & 23 & 11 & 19 & $53(17.7 \%)$ \\
\hline \multicolumn{5}{|l|}{$>$ Rp. $2.000 .000-$} \\
\hline 3.000 .000 & 18 & 2 & 18 & $38(12.7 \%)$ \\
\hline \multicolumn{5}{|l|}{$>$ Rp. $3.000 .000-$} \\
\hline 5.000 .000 & 33 & 29 & 63 & $125(41.7 \%)$ \\
\hline \multicolumn{5}{|l|}{$>$ Rp. $5.000 .000-$} \\
\hline 7.500 .000 & 4 & 22 & 0 & $26(8.7 \%)$ \\
\hline \multicolumn{5}{|l|}{$>$ Rp. 7.500.000 - } \\
\hline 10.000 .000 & 13 & 29 & 0 & $42(14.0 \%)$ \\
\hline >Rp. 10.000 .000 & 6 & 5 & 0 & $11(3.7 \%)$ \\
\hline
\end{tabular}

Source: Result of the research.

\section{Financial Knowledge}

Appendix 2. Questionnaire

1. Personal financial knowledge will help you to...

A. Avoid fraud in financial aspect

B. Buy various insurance policies to protect you from risks

C. Lead a financially secure life through forming a healthy shopping habit

D. All of the above is true

2. Your aim in personal financial planning is...

A. Establish an adequate financial recording system

B. Develop a healthy annual spending and income budget

C. Minimizing tax and insurance costs

D. Preparing a plan for future financial needs and goals

3. The following is the easiest asset to liquidate...
A. Money on the certificate of deposit
B. Money in the form of a check
C. Car
D. House

4. Your net worth is ... 

A. The difference between your expenditure and income
B. The difference between your total debt and assets
C. The difference between your in and out cash flow
D. Total savings in your bank

5. Inflation can cause various kinds of difficulties. The following group who suffers the most when an inflation occurs is...
A. A middle-aged married couple who are still working and currently saving for retirement
B. A young couple who are both working with no kids or any liability
C. Married couple with a fixed retirement allowance
D. A young couple who are both working with kids

6. If the inflation rate is $5 \%$ while the bank is giving $3 \%$ interest rate on your savings, then your money value will ...
A. Increase
B. Decrease
C. Remains the same
D. There is no relation

7. Your expenditure will not go over your budget if ...
A. You write more checks than what you have in your account
B. Your salary is Rp. 500.000 and credit costs Rp. 1.000.000
C. You often receive calls from a debt collector
D. Your debt is $30 \%$ of your monthly income is not the cost of renting an apartment.

8.
A. Security deposit
B. Monthly rent payment
C. Costs incurred for not complying with renting rules
D. The medical costs of a friend who fell on the sidewalk

9. If you rent an apartment for twelve months for Rp. 3.000.000 a month, but never used the apartment, you legally owe the owner:
A. Your security deposits
B. Your first month's rent of Rp. 3.000.000
C. Your whole twelve months' rent of Rp. 36.000.000
D. Nothing

10. Checking account reconciliation will ...
A. Balance your bank statement with your checkbook to determine if there is a mistake
B. Reconcile the current bank statement with the previous month's statement to determine if there was a mistake
C. Reduce outstanding checks on your checkbook balance to determine if your checks have been properly processed


D. Add outstanding checks to your checkbook balance to improve your credit rating.

11. When you save money in a bank, and the bank faces a problem, then the party that guarantees the safety of your money in the bank is...
A. Finance department
B. Local government
C. Savings board
D. Minister of finance

12. Mr. Anton stored Rp. 1.000 .000 for 3 months with an interest rate of $12 \%$ per year, the interest he gains will be...
A. Rp. 120.000
B. Rp. 12.000
C. Rp. 30.000
D. Rp. 36.000

13. Which of the following is WRONG about credit cards?
A. If the balance on your credit card is Rp.1.000.000 and you pay Rp.300.000, interest is put on your remaining balance which is Rp.700.000
B. The interest rate on your credit card is usually higher than the interest in certificate of deposit
C. Credit card companies will not charge penalty fees if you pay it off completely on the due date

14. If you want to invest Rp. 10.000 .000 today with an interest of $4 \%$ per year, next year your balance will be...
A. Higher if the interest is calculated daily instead of monthly
B. Higher if the interest is calculated quarterly instead of weekly
C. Higher if the interest is calculated annually instead of quarterly
D. Rp.10.400.000 regardless of how the interest is calculated

15. Certificate of deposit is issued by...
A. Company
B. Indonesian Stock Exchange
C. Bank
D. International banks only

16. High risk high return is an investment strategy more suited to...
A. An elderly person who has retired and is living on a fixed income
B. Middle-aged family who will need funds for their children's education in two years
C. None is correct, as they are all avoiding risks
D. A couple who just got married with no kids yet

17. The wrong statement in the following is...
A. Mutual funds owners have the right to tell their investment manager to buy a certain security 
BISMA (Bisnis dan Manajemen)

Volume 12 Issue 1, October 2019

E-ISSN 2549-7790, P-ISSN 1979-7192

Page 15-28

B. Mutual funds are diversification of a group of securities who use various means of investment

C. Mutual funds are investment companies that collect funds from investors and purchase various securities

D. Mutual funds ownership is proportional to the amounts of sheets you have

18. Return of mutual funds include...

A. Interest gained from cash

B. Interest gained from bonds

C. Capital gain from shares and bonds

D. All of the above

\section{Financial Behavior}

Choose the statement that best describes your behavior

\begin{tabular}{|c|c|c|c|c|c|}
\hline Statement & 1 & 2 & 3 & 4 & 5 \\
\hline \multicolumn{6}{|l|}{ I put some of the money I have in saving } \\
\hline \multicolumn{6}{|l|}{ I put some of my money for retirement plan } \\
\hline \multicolumn{6}{|l|}{ I have a target in managing my finance, both short and long term } \\
\hline \multicolumn{6}{|l|}{ I have and follow the budget that I planned for the month or the week } \\
\hline \multicolumn{6}{|l|}{ I pay my credit card bills fully and avoid additional fees } \\
\hline \multicolumn{6}{|l|}{ I avoid the reaching the limit of my credit card } \\
\hline \multicolumn{6}{|l|}{ My expenses have never been greater than my income } \\
\hline \multicolumn{6}{|l|}{ I need to cut down on daily expenses } \\
\hline \multicolumn{6}{|l|}{ I do not need credit cards when I run out of cash } \\
\hline I have money problems because I do not have enough money & & & & & \\
\hline
\end{tabular}

\section{Description:}

$1=$ strongly disagree; 2 = disagree; $3=$ fairly agree; $4=$ agree $; 5=$ strongly agree 